\title{
PENDEKATAN KEADILAN RESTORATIF DALAM IMPLEMENTASI SISTEM PERADILAN PIDANA ANAK DI INDONESIA
}

\section{(THE RESTORATIVE JUSTICE APPROACH TO THE IMPLEMENTATION OF CHILDREN'S CRIMINAL JUSTICE SYSTEM IN INDONESIA)}

\author{
Ali Muhammad \\ Politeknik Ilmu Pemasyarakatan \\ Alimuhammad32@gmail.com
}

\begin{abstract}
ABSTRAK
Sejak diberlakukannya Undang-Undang No. 11 Tahun 2012 Tentang Sistem Peradilan Pidana Anak di Indonesia perlu segera diupayakan sosialisasi kepada Aparat Penegak Hukum (APH) yang belum memahami dan mengetahui tentang kewajiban melakukan pendekatan keadilan Restoratif dalam implementasi Sistem Peradilan Pidana Anak. Norma yang mengatur tentang kewajiban melakukan pendekatan keadilan restoratif dalam penanganan Anak yang berhadapan dengan Hukum (ABH) tertuang dalam pasal 5 ayat 1 Undang-Undang Sistem Peradilan Pidana Anak dan Undang-Undang ini juga sudah mengadopsi instrumen Internasional Konvensi Hak Anak (KHA) yang sudah diratifikasi oleh pemerintah Republik Indonesia dengan keputusan Presiden Nomor 36 Tahun 1990 tentang Pengesahan Convention on the Rights of the Child (Konvensi tentang Hak-Hak Anak) selain peraturan internasional lainnya seperti Beijing Rules, Riyadh Guidelines dan Tokyo Rules yang tentunya sejalan dengan Undang-Undang Dasar 1945 tentang tujuan negara yang salahsatunya adalah untuk mewujudkan keadilan sosial dan memajukan kesejahteraan umum. Pendekatan keadilan restoratif ini tentunya memiliki semangat yang sama dengan nilai-nilai idiologi Pancasila, politik, sosial budaya bangsa Indonesia yang lebih mengedepankan penyelesaian melalui musyawarah untuk mufakat sehingga pendekatan keadilan restoratif ini juga merupakan salahsatu pembaharuan hukum yang lebih mengangkat nilai-nilai kearifan lokal dari Bangsa Indonesia. Pendekatan konseptual (conceptual approach) dan pendekatan perundang-undangan (statue approach) merupakan pendekatan yang digunakan dalam penelitian ini dan memaksimalkan impelemntasi pelaksanaan keadilan restoratif dalam setiap penanganan Anak yang Berhadapan dengan Hukum (ABH) pada setiap proses tahapan penyidikan, penuntutan dan pengadilan. Tujuan penelitian adalah untuk memberikan penegasan kepada setiap Aparat Penegak Hukum akan kewajiban melakukan pendekatan Keadilan Restoratif dalam setiap Penanganan $\mathrm{ABH}$.
\end{abstract}

Kata Kunci: Keadilan Restoratif, Sistem Peradilan Pidana Anak, Diversi, Anak Berhadapan Dengan Hukum

\section{ABSTRACT}

Since the enactment of Law No. 11 of 2012 concerning the Criminal Justice System for Children in Indonesia needs to be sought immediately for Law Enforcement Officials (APH) who do not understand and know about the obligation to adopt a Restorative justice approach in the implementation of the Child Criminal Justice System. The norm that regulates the obligation to approach restorative justice in the handling of Children dealing with the Law $(A B H)$ contained in article 5 paragraph 1 of the Child Criminal Justice System Law and this Law has also adopted the International instrument of the 
Convention on the Rights of the Child (CRC) ratified by the government of the Republic of Indonesia with a Presidential Decree Number 36 of 1990 concerning Ratification of the Convention on the Rights of the Child in addition to other international regulations such as the Beijing Rules, Riyadh Guidelines and Tokyo Rules which are certainly in line with the Constitution 1945 concerning the purpose of the country which was wrong was to realize social justice and promote public welfare. This restorative justice approach certainly has the same spirit as the ideological values of Pancasila, politics, and the Indonesian national socio-culture which prioritizes solutions through deliberation to reach consensus so that this restorative justice approach is also one of legal reforms that elevates the values of local wisdom from the Nation Indonesia. The conceptual approach and the approach to legislation (the statue approach) are the approaches used in this study and maximize the implementation of the implementation of restorative justice in every handling of children facing the law $(A B H)$ at each stage of the investigation, prosecution and trial. research is to provide confirmation to every Law Enforcement Officer of the obligation to take a Restorative Justice approach in every Handling of ABH.

Keywords: Restorative Justice, Child Criminal Justice System, Diversion, Children Dealing with Law

\section{PENDAHULUAN}

\section{A. Latar Belakang}

Anak adalah anugrah Tuhan Yang Maha Kuasa yang memiliki nilai sangat penting dalam menentukan keberlangsungan hidup sebuah bangsa dan negara, sehingga keberadaanya dalam setiap kondisi apapun menuntut perlindungan dan perlakuan yang ditujukan sepenuhnya untuk kepentingan terbaik bagi Anak dalam proses tumbuh dan berkembangnya. Sehingga dalam penanganan Anak yang Berhadapan dengan hukum yang selanjutnya disebut $\mathrm{ABH}$ memerlukan penangaan yang khusus dan sungguh-sungguh dari negara yang dalam hal ini diperankan oleh Aparat Penegak Hukum yang selanjutnya disebut APH karena secara nasional saat ini jumlah Kasus ABH cukup tinggi baik segi kualitas maupun kuantitasnya, seperti data yang saat ini ada di Sistem Data Base Pemasyarakatan Jumlah Anak yang berkonflik dengan Hukum di Indonesia pada tahun 2018 pada posisi bulan Juli gabungan antara tahanan dan narapidana Anak berjumlah 3.024 Anak ${ }^{1}$

Kondisi ini tentunya memerlukan suatu kebijakan hukum yag tepat untuk memastikan $\mathrm{ABH}$ tidak mendapatkan perlakuan yang

\footnotetext{
${ }^{1}$ Arief Syahrul Alam and Ani Purwati, 'Diversi Sebagai Wujud Kebijakan Pemidanaan Dalam Sistem Peradilan Pidana Anak Di Indonesia',
}

berisiko terhadap tumbuh dan kembangnya dikemudian hari. Sebelum berlakunya Undangundang No. 11 Tahun 2012 berlaku Undangundang No. 3 Tahun 1997 tentang Pengadilan Anak yang memiliki tujuan untuk melindungi dan mengayomi $\mathrm{ABH}$ agar Anak dapat menyongsong masa depannya lebih baik serta pemberian pembinaan agar Anak memiliki jati diri untuk mewujudkan manusia yang dapat mandiri, bertanggung jawab, dan berguna bagi dirinya, keluarga, masyarakat, bangsa dan Negara. Harapan ini menjadi tujuan dari keberadaan Undang-Undang No. 3 Tahun 1997 namun seiring perjalan dari Undang-undang ini faktanya Anak masih diposiskan sebagai objek dan diperlakukan tidak sesuai dengan harkat dan martabat Anak yang berdampak kepada kerugian untuk tumbuh dan berkembangnya Anak seperti timbulnya lebeling atau stigma terhadap Anak, Strees, prisonisasi dan tidak terpenuhinya hak-hak yang bersipat mendasar secara baik seperti; kesehatan, pendidikan dan latihan keterampilan dan juga Undang-undang No.3 Tahun 1997 ini belum melibatkan peran serta masyarakat, pemerintah dan lembaga negara lainnya untuk sama-sama meningkatkan kesejahteraan Anak dan pada tataran pelaksanaan Udang-Undang ini belum menerapkan lembaga diversi dalam

Journal de Jure, 7.2 (2016), 181

<https://doi.org/10.18860/j-fsh.v7i2.3524>. 
rumusannya, yang menyebabkan banyak perkara pidana yang bermuara dari tindak kenakalan anak yang sifatnya Juvenile Delinquency semata, yang seharusnya tidak perlu diproses sampai ke arah pidana. $^{2}$ Berdasarkan penelitian, kebijakan penjatuhan pidana (khususnya pidana penjara) terhadap anak nakal (delinkuensi) menunjukan adanya kecenderungan bersifat merugikan perkembangan jiwa anak dimasa mendatag. Kecenderungan bersifat merugika ini akibat dari efek penjatuhan pidana yang berupa stigma yang disebabkan oleh penggunaan model peradilan retributif, dan tidak menggunakan model pendekatan peradilan restoratif. ${ }^{3}$ Kondisi inilah yang menuntut Negara untuk membuat kebijakan baru terkait perlakuan terhadap $\mathrm{ABH}$ untuk mewujudkan pembaharuan hukum yang lebih memperhatikan masa depan dan pemenuhan hak-hak dasar Anak, sehingga anak tidak mengalami kondisi yang lebih buruk lagi disaat Anak masuk kedalam sistem peradilan Pidana Anak atau Berhadapan dengan hukum. inilah yang mendasari penggantian Udangundang Nomor 3 Tahun 1997 tentang Pengadilan Anak (Lembaran Negara Republik Indonesia Tahun 1997 Nomor 3, Tambahan Lembaran Negara Republik Indonesia Nomor 3668) menjadi Undang-undang No. 11 Tahun 2012 Tentang Sistem Peradilan Pidana Anak, Lembaran Negara Republik Indonesia Tahun 2012 Nomor 153 yang disahkan di Jakarta pada tanggal 30 Juli $2012^{4}$.

Upaya menghindari dampak negatif selama proses peradilan pidana Anak yang sudah diatur dalam konvensi atau hukum internasional seperti The Beijing Rules telah memberikan otoritas kepada aparat penegak hukum untuk mengambil tindakan-tindakan kebijakan dalam

\footnotetext{
${ }^{2}$ Adhiyoga Wira Dewata and others, 'Diversi Sebagai Aktualisasi Konsep Restorative Justice Dalam Penegakan Hukum (Studi Penanganan Tindak Pidana Oleh Anak Di Wilayah Pengadilan Negeri Semarang)', Diponegoro Law Review, 5.11 (2016), 1-11.

${ }^{3}$ Angkasa, Saryono Hanadi, and Muhammad Budi Setyadi, 'Model Peradilan Restoratif Dalam Sistem Peradilan Anak ( Kajian Tentang Praktik Mediasi Pelaku Dan Korban Dalam Proses Peradilan Anak
}

menangani atau menyelesaikan masalah pelanggaran Anak dengan tidak mengambil jalan formal antara lain menghentikan atau tidak meneruskan kepada proses peradilan atau mengembalikan dan menyerahkan kembali kepada masyarakat dan bentuk-bentuk kegiatan pelayanan sosial lainnya ${ }^{5}$. Dalam implementasinya setelah 4 tahun undangundang Sistem Peradilan Pidana Anak diberlakukan khusunya dalam plekasanaan Diversi dalam rangka mendorong keadilan restortif masih banyak kendala yang dihadapi oleh Aparat Penegak Hukum dilapangan,diantaranya: Pertama, Anak berkonflik dengan hukum masih menjalani proses peradilan pidana dan dijatuhi sanksi penjara dengan jumlah cukup tinggi. ${ }^{6}$ Kedua, terbatasnya sarana dan prasarana dalam perlindungan $\mathrm{ABH}$ selama proses peradilan (pra maupun pasca putusan pengadilan) dan minimnya jumlah Lembaga Pembinaan Khusus Anak (LPKA) di tiap-tiap provinsi sehingga belum sepenuhnya dipisahkan antara LPKA dan Lapas Dewasa, ${ }^{7}$ dan Lembaga Penempatan Anak Sementara. Ketiga, kondisi riil dilapangan data diversi belum tersistematis mulai dari tingkat kepolisian baik dari Polsek sampai Polrestabes, ${ }^{8}$ Balai Pemasyarakatan (Bapas), Keempat, belum tersedianya nomenklatur yang mengatur tentang Lembaga Penempatan Anak Sementara (LPAS), Kelima, Koordinasi antar aparat penegak hukum (Kepolisian, Kejaksaan, Mahkamah Agung, Kementerian Hukum dan HAM, Kementerian Sosial, Kementerian Pendidikan, dan Kementerian Kesehatan masih belum optimal dalam melaksanakan tugas dan fungsinya. Melihat kondisi keterbatasan dan kendalakendala yang dihadapi tersebut penelitian ini

Di Wilayah Hukum Balai Pemasyarakatan Purwoker)', Jurnal Dinamika Hukum, 9.3 (2009), 186-204.

${ }^{4}$ Gilang Ramadhan Suharto, 'Restorative Justice Peradilan Pidana Anak Di Indonesia', Lex Crimen, IV.1 (2015), 35-45.

${ }^{5}$ Alam and Purwati.

${ }^{6}$ Alam and Purwati.

${ }^{7}$ Alam and Purwati.

${ }^{8}$ Alam and Purwati. 
juga bertujuan untuk mengkaji dan menganalisa tentang implementasi Sistem Peradilan Pidana Anak khusunya dalam pendekatan keadilan restoratif yang dilaksanakan oleh Aparat Penegak Hukum dalam penanganan Anak Yang Berhadapan Dengan Hukum selain memberikan penekanan tentang kewajiban melakukan pendekatan keadilan restoratif dalam setiap penangaan Anak Yang Berhadapan dengan Hukum $(\mathrm{ABH})$.

\section{PEMBAHASAN}

\section{A. Keadilan restoratif (Restorative Justice)}

Deklarasi Bangkok tahun 2005 yang diselenggaraka oleh Lembaga Perserikatan Bangsa-Bangsa (PBB) mengeluarkan himbauan bagi setiap negara yang sudah meratifikasi Konvensi Hak Anak dan Deklaration of Human Right (Duham) untuk menggunakan konsep pendekatan keadilan restoratif dalam pelaksanaan sistem peradilan pidana, harapannya adalah agar setiap penyelesaian masalah hukum harus lebih mengutamakan konsep yang lebih menghargai hak-hak korban dan lebih berorientasi kepada rehabilitasi pelaku dengan berupaya untuk mencari alternatif-alternatif baru dalam memberikan perlakuan terhadap pelanggar hukum sebagai upaya untuk menghindari dampak buruk dari pemenjaraan yang saat ini masih sering dijadikan prioritas utama dalam penyelesaian masalah hukum dalam sistem peradilan pidana. ${ }^{9}$

Keadilan Restoratif atau Restorative justice merupakan suatu proses yang melibatkan semua pihak yang terlibat dalam sutu tindak pidana untuk bersama-sama mengatasi masalah serta menciptakan suatu kewajiban untuk membuat segala sesuatunya menjadi lebih baik dengan melibatkan korban, anak, dan masyarakat dalam mencari solusi untuk memperbaiki serta menentramkan hati yang tidak berdasarkan pembalasan. ${ }^{10}$ Norma

\footnotetext{
${ }^{9}$ Suharto.

${ }^{10}$ Dewata and others.
}

tentang Keadilan Restoratif tau restorative Justice tertuang juga dalam pasal 1 ayat (6) undang-Undang Nomor 11 Tahun 2012 Tentang Sistem Peradilan Pidana Anak yaitu “ Keadilan Restoratif adalah penyelesaian perkara tidak pidana dengan melibatkan pelaku, korban, keluarga pelaku/korban, dan pihak lain yang terkait untuk bersama-sama mencari penyelesaian yang adil dengan menekankan pemulihan kembali pada keadaan semula, dan bukan pembalasan" ${ }^{11}$ Pendekatan Keadilan Restoratif ini jelas menekankan kepada semangat pemulihan dalam perlakuan terhadap Anak yang berhadapan dengan hukum baik sebagai Anak Pelaku, Anak Korban maupun Anak saksi termasuk pihakpihak lain yang berkonflik dengan hukum.

Pentingnya semangat Keadilan Restoratif dalam penyelesaian konflik Hukum dari masing-masing pihak yang berkonflik mewajibkan perlunya penelitian yang seksama dan objektif tentang kenapa terjadinya konflik tersebut sehingga Undang-Undang nomor 11 Tahun 2012 Tentang Sistem Peradilan Pidana Anak mewajibkan dalam setiap penyelesaian perkara anak disetiap tingkatan pemeriksaan, penyidikan, penuntutan umum, serta hakim wajib untuk mempertimbangkan tindak pidana yang dilakukan anak dengan melihat umur anak pada saat melakukan tindak pidana, latarbelakang keluarga, kondisi lingkungan sosial, pendidikan anak, jenis tindak pidana yang dilakukan dan hal-hal lain yang signifikan berpengaruh terhadap sikap dan perilaku anak yang data ini diperoleh dari hasil penelitia kemasyarakatan dari Pembimbing Kemasyarakatan dari Balai Pemasyarakatan. ${ }^{12}$

Penanganan Anak yang Berhadapan Dengan Hukum dengan mengedepakan semangat Keadilan Restoratif semakin kuat disaat diberlakukannya Undang-Undang Nomor 11 Tahun 212 Tentang Sistem Peradilan Pidana Anak hal ini dapat dilihat dari ketentuan umum dalam beracara di peradilan pidana yang

\footnotetext{
${ }^{11}$ Pemerintah RI, UU No 11 Tahun 2012 Tentang Sistem Peradilan Pidana Anak, 2012, pp. 1-103.

12 Dewata and others.
} 
tertuang dalam pasal 16 sampai dengan pasal 25 Undang-Undang Sistem Peradilan Pidana Anak, sedangkan tahap penyidikan dalam perkara anak diatur dalam pasal 26 sampai pasal 29 Undang-Undang Nomor 11 Tahun 2012 tentang Sistem Peradilan Pidana Anak. ${ }^{13}$ Pendekatan keadilan restoratif juga merupakan upaya untuk mendukung dan melaksanakan ketentuan yang diatur dalam pasal 16 ayat (3) Undang-Undang Nomor 23 Tahun 2002 Tentang Perlindungan Anak jo UndangUndang Republik Indonesia Nomor 35 Tahun 2014 Tentang Perubahan atas Undang-Undang Nomor 23 Tahun 2002 Tentang Perlindungan Anak, yaitu bahwa "penangkapan, penahanan, atau tindak pidana penjara anak hanya dilakukan apabila sesuai dengan hukum yan berlaku dan hanya dapat dilakukan sebagai upaya terakhir". ${ }^{14}$ Penyelesaian perkara Anak yang berhadapan dengan Hukum dengan mengedepankan semangat keadilan restoratif sejalan dengan nilai-nilai luhur kepribadian Bangsa Indonesia yang tertuang dalam Pancasila sebagai idiologi Bangsa Indonesia seperti nilai-nilai keadilan, musyawarah dan mufakat dan gotong royong, yang nilai-nilai luhur ini terinternalisasi kedalam sistem hukum yang berlaku di Indonesia saat ini.

Penjelasan UU No.8 Tahun 1981 tentang Kitab Undang-Undang Hukum Acara Pidana (KUHAP), pada penjelasan umumnya menjelaskan ada 10 asas yang harus ditegakan dalam pelaksaaan KUHAP. Asas yang harus ditegakan oleh penegak hukum dalam pelaksanaan tugas dan fungsinya menekankan untuk dilaksanakannya penanganan yang memiliki semangat keadilan restoratif dalam setiap proses tahapan pra-ajudikasi, ajudikasi dan pos-ajudikasi.

1. Tahap pra- Ajudikasi (penyelidikan dan Penyidikan)

Kitab Undang-Undang Hukum Acara Pidana (KUHAP) Pasal 1 angka 1 s/d 5 menjelaskan bahwa salahsatu dari keadilan restorative justice adalah Diversi. ${ }^{15}$ Saai ini di Indonesia sudah ada norma yang mengatur secara khusus tentang pelaksanaan Diversi dalam upaya pendekatan keadilan restoratif khususnya dalam penanganan Anak Yang Berhadapan Dengan Hukum yang tertuang dalam pasal 7 angka 1 dan 2 serta mekanisme pelaksanaanya sudah mengedapankan semangat keadilan Restoratif sesuai dengan bunyi pasal 5 angka 1 Undang-Undang Nomor 11 Tahun 2012 Tentang Sistem Peradilan Pidana Anak. ${ }^{16}$ Undang-Undang Sistem Peradilan Pidana Anak secara khsusus sudah mengatur norma tentang wajibnya Aparat Penegak Hukum untuk mengedepankan semangat keadilan restoratif termasuk pada pada saat proses penyelidikan dan penyidikan. Secara umum UndangUndang No. 8 Tahun 1981 tentag KUHAP belum mengatur tentang Diversi dalam sistem peradilan pidana secara umum, namun ada kewenangan diskresi pada Polisi yang mirip dengan diversi sesuai dengan Pasal 7 huruf j dan Pasal 16 ayat (1) huruf i dan ayat (2) yang dipertegas Pasal 18 ayat (1) UU No.2 Tahun 2002 tentang Kepolisian Negara Republik Indonesia. $^{17}$

2. Tahap Ajudikasi (penuntutan dan persidangan)

Pada tahap Ajudikasi Jaksa sebagai penuntut umum yang memiliki peran dalam penuntutan sebagaimana pasal 41 ayat 1 Undang-Undang Sistem Peradilan Pidana Anak, memiliki kewajiban untuk megupayakan Diversi sebagai bagian dari upaya pendekatan keadilan restoratif sebagaimana bunyi pasal 42 ayat 1 "Penuntut Umum wajib mengupayakan Diversi paling lama 7 (tujuh) hari setelah menerima berkas perkara dari Penyidik". Hal ini menunjukan bahwa pada tahap

\footnotetext{
${ }^{16}$ Pemerintah RI, UU No 11 Tahun 2012 Tentang Sistem Peradilan Pidana Anak.

${ }^{17}$ Suharto.
}

${ }^{13}$ Dewata and others.

15 Suharto. 
Ajudikasi juga upaya mengedepakan semanagat keadilan restoratif menjadi suatu keharusan yang tidak boleh diabaikan oleh Aparat Penegak Hukum khususnya jaksa sebagai penuntut umum. ${ }^{18}$ Dalam KUHAP wewenang Jaksa untuk melakukan diversi belum diatur secara eksplisit, namun kesempatan dan peluang untuk menjalankan Diversi dengan semanagat keadilan restoratif dimungkinkan hal ini sesuai dengan bunyi Pasal 30 ayat (1) UU No. 16 Tahun 2004 tentang Kejaksaan Republik Indonesia dan Pasal 14 huruf h UU No.8 Tahun 1981 tentang KUHAP, hal ini dapat terwujud apabila dilakukannya perintah diversi atau adanya itikad baik dari pelaku maupun korban untuk melakukan mediasi sejak awal penyidikan. ${ }^{19}$

Pada tahap persidangan Hakim
memiliki kewajiban juga untuk
mengedepankan semangat keadilan restoratif sebagaimana bunyi pasal 5 Undang-undang Sistem Peradilan Pidana Anak, hal ini diperkuat pula oleh peraturan Mahkamah Agung nomor 4 tahun 2014 tentang pedoman pelaksaaan Diversi dalam sistem peradilan pidana anak pasal 3 yang mewajibkan Hakim Anak untuk mengupayakan Diversi dalam hal Anak didakwa melakukan tindakan pidana yang diancam dengan pidana penjara di bawah 7 (tujuh) tahun dan didakwa pula dengan tindakan pidana yang diancam dengan pidana penjara 7 (tujuh) tahun atau lebih dalam bentuk surat dakwaan subsidiaritas, alternatif, kumulatif maupun kombinasi (gabungan). ${ }^{20}$ Pelaksanaan penanganan masalah Anak yang Berhadapan dengan Hukum dengan berdasarkan kepada Peraturan Mahkamah Agung ini menyebabkan hakim dalam penyelesaian masalah Anak lebih progresif dari Undang-Undang Sistem Peradilan pidana

${ }^{18}$ Pemerintah RI, PP 65 Tahun 2015 Tentang Pelaksanaan Diversi Dan Penanganan Anak Yang Belum Berumur 12 (Dua Belas) Tahun, 2015, pp. $1-72$.
Anak dan Peraturan Pemerintah Nomor 65 Tahun 2015 tentang Pedoman Pelaksanaan Diversi dan Penanganan Anak dibawah 12 tahun, hal ini dapat dicermati dari pasal 7 undang-undang Sistem Peradilan Pidana Anak dan pasal 3 Peraturan Pemerintah nomor 65 tahun 2015 yang mensyaratkan Diversi hanya dapat dilaksanakan apabila Anak Pelaku diancam dengan penjara di bawah 7 (tujuh) tahun; dan bukan merupakan pengulangan tindak pidana sedangkan di Peraturan Mahkamah Agung nomor 4 pasal 3 Diversi dapat juga dilaksanakan kepada Anak pelaku yang diancam diancam dengan pidana penjara di bawah 7 (tujuh) tahun dan didakwa pula dengan tindakan pidana yang diancam dengan pidana penjara 7 (tujuh) tahun atau lebih dalam bentuk surat dakwaan subsidiaritas, alternatif, kumulatif maupun kombinasi (gabungan).

Keadilan Restoratif saat ini dalam sistem peradilan pidana umum belum diatur walaupun apabila Hakim akan menerapkan keadilan restoratif dalam proses penyelesaian perkara hal ini dapat dimungkinkan, sesuai dengan ketentuan pasal 10 ayat (1) dan Pasal 5 ayat (1) UU No. 48 Tahun 2009 tentang kekuasaan kehakiman. $^{21}$

3. Tahap Pos- Ajudikasi ( Pelaksanaan Hukuman)

Pada tahap Pos-Ajudikasi atau pelaksanaan hukuman, lembaga yang berperan dalam upaya menjalankan pendekata keadilan restoratif dalam penanganan $\mathrm{ABH}$ adalah Lembaga Pembinaan Khusus Anak (LPKA ) sebagai mana pasal 85 ayat (3) UU No. 11 Tahun 2012 tentang Sistem Peradilan Pidana Anak yang menjelaskan bahwa guna untuk pemulihan Anak sebagai tujuan dari keadilan restoratif Lembaga Pembinaan

\footnotetext{
${ }^{19}$ Suharto.

20 'Perma_04_2014 (1).Pdf'.

${ }^{21}$ Suharto.
} 
Khusus Anak LPKA wajib menyelengarakan pendidikan, pelatihan, keterampilan, pembinaan, dan pemenuhan hak lain sesuai dengan ketentuan peraturan perundang-undangan. ${ }^{22}$ Amanat Undangundang ini menuntut setiap Lembaga Pembinaan Khusus Anak yang sebelumnya bernama Lembaga Pemasyarakatan Anak (LAPAS Anak) untuk mereformasi sistem pelaksanaan perlakuan terhadap Anak dalam menjalani masa pidanya yang berdampak juga kepada dukungan kesiapan Sumerdaya Manusia (petugas) dan sarana prasarana penunjang lainnya. Seperti yang dilakukan oleh Lembaga Pembinaan Khusus Anak Palembang yang telah berupaya memperbaharui suasana Lembaga Pembinaan Khusus Anak menjadi lebih ramah Anak dan tidak menimbulkan kesan seram dan tidak manusiawi dengan mencat warna bangunan dengan warna-warna cerah dan segar serta berhasil membangun sistem penyelenggaraan pendidikan bagi Anak dari mulai jenjang Sekolah Dasar, Sekolah Menegah Pertama dan Sekolah Menegah Atas yang sesuai dengan kebutuhan Anak dan melibatkan peran serta masyarakat dan Pemerintah Daerah. Begitupula yang telah dilakukan oleh Lembaga Pembinaan Khusus Anak lainnya seperti di Lembaga Pembinaan Khusus Anak Tanggerang yang dalam beberapa tahun terakhir sudah melakukan pembaharuan dalam menciptakan suasana Lembaga Pembinaan Khusus Anak yang lebih responsif dalam mewujudkan kepentingan terbaik untuk Anak, sehingga hal ini dapat memaastikan terpenuhinya hak-hak Anak untuk memperoleh pembinaan, pembimbingan, pengawasan, pendampingan, pendidikan dan pelatihan, serta hak lain sesuai dengan ketentuan

\footnotetext{
${ }^{22}$ Pemerintah RI, UU No 11 Tahun 2012 Tentang Sistem Peradilan Pidana Anak.

${ }^{23}$ Pemerintah RI, UU No 11 Tahun 2012 Tentang Sistem Peradilan Pidana Anak.
}

peraturan perundang-undangan. ${ }^{23}$

Selain Lembaga Pembinaan Khusus Anak (LPKA) ada unit lain yang juga memiliki peran penting untuk menjalankan perannya pada tahap pos- Ajudikasi yaitu Balai Pemasyarakatan (BAPAS) yang didalamnya ada petugas Pembimbing Kemasyarakatan yang memiliki tugas untuk menentukan program pembinaan Anak di LPKA bersama dengan petugas pemasyarakatan lainnya, melakukan pendampinga, pembimbingan, dan pengawasan terhadap Anak yang berdasarkan putusan pengadilan dijatuhi pidana atau dikenai tindakan; dan melakukan pendampingan, pembimbingan, dan pengawasan terhadap Anak yang memperoleh asimilasi, pembebasan bersyarat, cuti menjelang bebas, dan cuti bersyarat, ${ }^{24}$ walaupun tugas Pembimbing Kemasyarakatan saat ini berdasarkan UU No. 11 Tahun 2012 tentang Sistem Peradilan Pidana Anak sudah bekerja sejak pra-Ajudikasi sesuai dengan pasal 27 ayat (1) dimana Penyidik dalam melakukan penyidikan terhadap perkara Anak, Penyidik wajib meminta pertimbangan atau saran dari Pembimbing Kemasyarakatan setelah tindak pidana dilaporkan atau diadukan termasuk juga sesuai dengan apa yang diatur pada pasal 13 ayat (1) huruf (a) pada Peraturan Pemerintah Republik Indonesia Nomor 65 Tahun 2015 tentang Pedoman Pelaksanaan Diversi dan Penanganan Anak yang Belum berumur 12 (Dua Belas) Tahun. ${ }^{25}$ hal ini merupakan perwujudan dari upaya untuk demi pemenuhan kepentingan terbaik untuk Anak guna terwujudnya pemulihan Anak dari hidup, kehidupan dan peghidupannya seuai dengan apa yang menjadi tujuan pemasyarakatan yaitu re-

\footnotetext{
${ }^{24}$ Pemerintah RI, UU No 11 Tahun 2012 Tentang Sistem Peradilan Pidana Anak.

${ }^{25}$ Pemerintah RI, PP 65 Tahun 2015 Tentang Pelaksanaan Diversi Dan Penanganan Anak Yang Belum Berumur 12 (Dua Belas) Tahun.
} 
integrasi sosial.

\section{PENUTUP}

A. Kesimpulan

Pendekatan Keadilan restoratif dalam implementasi sistem peradilan pidana Anak adalah suatu kewajiban yang sudah diamanatkan oleh Undang-undang Nomor 11 Tahun 2012 tentang Sistem Peradilan Pidana Anak dan semanagat keadilan restoratif dalam penyelesaian $\mathrm{ABH}$ merupakan juga perwujudan dari nilai-nilai luhur Bangsa Indonesai yang tertuang dalam Pancasila sebagai Idiologi Bangsa yang mempengaruhi sistem Hukum Indonesia.

Kewajiban pendekatan keadilan restoratif dalam penyelesaian masalah perkara pidana Anak dilakukan sejak dari paraajudikasi, ajudikasi dan pos-ajudikasi.

Pendekatan keadilan restoratif dalam penyelesaian masalah perkara Anak didasarkan kepada upaya yang menyeluruh dari pemerintah untuk memastikan pulihnya para pihak yang berkonflik baik Anak sebagai Pelaku, Anak sebagai Korban termasuk Anak sebagai Saksi sehingga tercapai tujuan dari keadilan restoratif yaitu perdamaian antara korban dan Anak, penyelesaian perkara Anak dapat diselesaikan di luar proses peradilan, menghindarkan Anak dari perampasan kemerdekaan, mendorong masyarakat untuk berpartispasi, menanamkan rasa tanggungjawab Anak dan yang terpenting menghindari stigma negatif pada Anak.

Dalam implementasinya pendekatan keadilan restoratif masih bayak yang harus diperbaiki dan disiapkan yang mencakup sosialisasi Undang-Undang, menyamakan persepsi Aparat Penegak Hukum dari mulai

\footnotetext{
${ }^{26}$ Pemerintah RI, Peraturan Pemerintah Nomor 8 Tahun 2017 Tentang Tata Cara Pelaksanaan Koordinasi, Pemantauan, Evaluas, Dan Pelaporan Sistem Peradilan Pidana Anak, 2017, pp. 1-14.
}

Penyidik, Penuntut umum, Hakim, Pembimbing Kemasyarakatan termasuk stikeholder lainnya yang ikut terlibat dalam implementasi Sistem Peradilan Pidana Anak seperti Pekerja Sosial dan petugas lainnya, termasuk dukungan sarana dan prasarananya dan ketersediaan Unit Pelaksana Teknis seperti Lembaga Penempatan Anak Sementara (LPAS), Lembaga Pembinaan Khusus Anak (LPKA), Lembaga Penyelengagra Kesejahteraan Sosial (LPKS), Balai Pemasyarakatan (BAPAS) dan juga Polsek, Polres dan Pengadilan.

Kesiapan peraturan turunan dari UndangUndang Nomor 11 Tahun 2012 tentang Sistem Peradilan Pidana Anak juga menjadi hal yang perlu segera diselesaikan dan disosialisasikan yang saat ini pemerintah sudah berhasil menghasilkan beberapa peraturan pemerintah yang diamanatkan seperti Peraturan Pemerintah Nomor 65 tahun 2015 Tentang Pedoman Diversi dan Penangaan Anak dibawah 12 Tahun, Peraturan Pemerintah Nomor 8 tahun 2017 Tentang Tata Cara Pelaksanaan Koordinasi, Pemantauan, Evaluasi, dan Pelaporan Sistem Peradilan Pidana Anak. ${ }^{26}$ Dan Peraturan Pemerintah Nomor 9 tahun 2017 Tentang Pedoman Register Perkara Anak dan Anak Korban yang juga menjadi amanat pasal 25 ayat (2) Undang-Undang Sistem Peradilan Pidana Anak yang mewajibkan registrasi Anak khusus dalam setiap penanganan perkara Anak. ${ }^{27}$

B. Saran

Saran Penulis agar implementasi pendekatan Keadilan Restoratif dalam sistem peradilan pidana Anak dapat terimplementasi dengan baik adalah dengan menanamkan pemahaman yang baik kepada Aparat Penegak Hukum tentang manfaat penegakan hukum dengan

\footnotetext{
${ }^{27}$ Pemerintah RI, Peraturan Pemerintah Nomor 9 Tahun 2017 Tentang Pedoman Reistrasi Perkara Anak Dan Anak Korban, 2017, pp. 1-19.
} 
pendekatan keadilan restoratif yang mengutamakan kepada prinsif-prinsif kepentingan terbaik bagi para pihak baik pada korban, pelaku, keluarga korban/pelaku serta masyarakat yang bertujuan untuk pemulihan bukan pembalasan.

Pelibatan peran serta masyarakat dan sosalisasi yang menyeluruh kepada masyarakat tentang sistem peradilan pidana Anak yang sudah mewajibkan pendekatan keadilan restoratif dalam penyelesaian perkara Anak sehingga masyarakat memahami dan ikut mendukung jalannya sistem peradilan pidana Anak.

Sesuai dengan amanat Undang-undang sistem peradilan pidana Anak perlu segera pemerintah menyiapkan dukungan yang memadai terkait sarana dan prasarana dan ketersediaan jumlah petugas yang akan menjalankannya seperti; setiap kantor kepolisian memiliki Penyidik Anak, setiap Kejaksaaan memiiki Penuntut Umum Anak, setiap pengadilan memiliki Hakim Anak, ketersediaan Balai Pemasyarakatan disetiap Kabupaten/kota, ketersediaan LPAS dan LPKA disetiap provinsi termasuk ketersediaan Lembaga Penyelenggara Kesejahteraan sosial sebagai tempat rehabilitasi dan pemulihan Anak.

Perlu dibentuk Tim Kelompok kerja Sistem Peradilan Pidana Anak di setiap Daerah atau Provinsi yang dapat menjadi wadah untuk memudahkan koordinasi antara Aparat Penegak Hukum (APH) dan Stikeholder terkait dalam implementasi Sistem Peradilan Pidana Anak, sehingga hal ini akan memperlancar proses penanganan Anak Berhadapan Dengan Hukum karena masing-masing APH dan sikeholer terkait sudah satu visi dan persefsi yang sama.

Terakhir sebagai upaya untuk memastikan seluruh penanganan Anak yang Berhadapan Dengan Hukum berjalan dengan baik sesuai dengan amanat Undang-
Undang Nomor 11 tahun 2012 dan Peraturan Pemerintah nomor 65 tahun 2015 tentang Pedoman Pelaksanaan Diversi dan Penanganan Anak dibawah 12 tahun perlu dilakukan monitoring dan evaluasi dari pemerintah khususnya kementerian atau Lembaga yang menangani bidang Hukum dan HAM serta Perlindungan Anak sehingga dapat diukur dan dinilai ketercapaian tujuan keadilan restoratif dalam penanganan Anak termasuk kendalakendala yang dihadapi yang perlu penyelesaia segera, sehingga implementasi Sistem peradilan pidana Anak akan semakin baik.

\section{DAFTAR PUSTAKA}

Alam, Arief Syahrul, and Ani Purwati, 'Diversi Sebagai Wujud Kebijakan Pemidanaan Dalam Sistem Peradilan Pidana Anak Di Indonesia', Journal de Jure, 7 (2016), 181 $<$ https://doi.org/10.18860/jfsh.v7i2.3524>

Angkasa, Saryono Hanadi, and Muhammad Budi Setyadi, 'Model Peradilan Restoratif Dalam Sistem Peradilan Anak ( Kajian Tentang Praktik Mediasi Pelaku Dan Korban Dalam Proses Peradilan Anak Di Wilayah Hukum Balai Pemasyarakatan Purwoker)', Jurnal Dinamika Hukum, 9 (2009), 186-204

Dewata, Adhiyoga Wira, R B Sularto, Tri Laksmi Indraswati, Program Studi, S Ilmu, Fakultas Hukum, and others, 'Diversi Sebagai Aktualisasi Konsep Restorative Justice Dalam Penegakan Hukum (Studi Penanganan Tindak Pidana Oleh Anak Di Wilayah Pengadilan Negeri Semarang)', Diponegoro Law Review, 5 (2016), 1-11

Pemerintah RI, Peraturan Pemerintah Nomor 8 Tahun 2017 Tentang Tata Cara Pelaksanaan Koordinasi, Pemantauan, Evaluas, Dan Pelaporan Sistem Peradilan Pidana Anak, 2017, pp. 1-14 
- Peraturan Pemerintah Nomor 9

Tahun 2017 Tentang Pedoman Reistrasi

Perkara Anak Dan Anak Korban, 2017, pp. 1-19

, PP 65 Tahun 2015 Tentang

Pelaksanaan Diversi Dan Penanganan

Anak Yang Belum Berumur 12 (Dua

Belas) Tahun, 2015, pp. 1-72

, UU No 11 Tahun 2012 Tentang

Sistem Peradilan Pidana Anak, 2012, pp.

1-103

'Perma_04_2014(1).Pdf'

Suharto, Gilang Ramadhan, 'Restorative Justice Peradilan Pidana Anak Di

Indonesia', Lex Crimen, IV (2015), 35-

45 